\title{
Effect of Seasonal Herbage Allowance on Bolus Weights of Cattle
}

JERRY W. STUTH AND RAYMOND F. ANGELL

\section{Abstract}

Technology has recently made it possible to count forage boli consumed daily in ruminants. This technique can presently be used to measure grazing time and rates of nutrient intake. However, to determine total daily intake, the influence of inherent variations in bolus weight and associated forage conditions must be known. An attempt was made to determine if degree of uniformity in forage boli weights were statistically nonsignificant to be counted and used as a measure of daily dry matter intake of an animal. Herbage allowances varying from 15.4 to $3.4 \mathrm{~kg} \mathrm{DM} / 100 \mathrm{~kg} \mathrm{BW} /$ day did not have a significant effect on bolus weights in mature cows grazing bahiagrass pastures during mid-summer and early winter $(P \leq 0.05)$. Cow size and season of the year also had no significant effect on bolus weight. Bolus weight of the cows averaged $4.4 \pm 0.1 \mathrm{~g}$ across seasons and cows.

Much effort has been directed toward relating forage intake of livestock to sward characteristics by measurement of size and rate of biting by the grazing animal (Allden and Whittaker 1970, Stobbs 1975, Chacon et al. 1976, Chacon and Stobbs 1976). Allden and Whittaker (1970) noted that as tiller height increased, size or weight of bite increased and rate of biting decreased. Hence, intake remained static over nonlimiting range forage availabilities. It appears that an animal has a strong tendency to maintain a given level of daily intake by varying bite size and grazing time (Spedding et al. 1966). The end result of these prehensile measurements is the swallowed bolus. Since rate of intake $(\mathrm{g} / \mathrm{min})$ by the animal was static in the Allden and Whittaker (1970) study, it would appear that the animal can maintain a static intake by creating boli that have little variation in dry matter weight. Thus, rate of swallowing boli and time spent grazing would determine daily intake of an animal.

This hypothesis would imply that the animal gathers forage in its mouth until a "critical" density or weight is attained to form the bolus. The shorter the vegetation the greater time spent forming the bolus. If grazing time does not exceed some inherent behavioral limitation of the animal, intake can be maintained at a stable level under nonlimiting forage conditions by adjusting grazing time. If the forage bolus is uniform across a wide array of forage conditions, then measurements of daily swallowing events of boli should provide a technique which measures daily intake and avoids the fluctuations in size and bite and rate of biting associated with variable forage availabilities.

Information to date on swallowed boli is limited to confined animals fed known feed sources (Schalk and Amadon 1928, Bailey 1961, Gill et al. 1966). Boli in these studies were collected by partial evacuation of the rumen and collection by hand of the swallowed bolus at the cardia in the rumen. Access for collection was provided by a rumen fistula. Bolus weight varied among studies, cows, and feed source. In general, as initial dry matter density of a feed source increased, bolus weight increased. The boli in these studies were reasonably uniform within each feed source and cow.

\footnotetext{
Authors are assistant professor and research technician, Department of Range Science, Texas Agricultural Experiment Station, Texas A\&M University System College Station, respectively. Published with permission of the Director, Texas Agricultural Experiment Station as TA 16095

Received for publication May 5, 1980
}

Recently, Stoner et al. $(1979,1980)$ and Stuth et al. (1981) described systems capable of measuring the various swallowing events of cattle, goats, and whitetailed deer. They were able to identify and distinguish among swallowing events of green forage. hay, concentrate feed, water, and regurgitation. In light of these findings, it appears that more information is needed to characterize dynamics of bolus weight under actual grazing situations in order that this information could be used to develop a new technique for determination of intake of animals.

It is the purpose of this paper to test the hypothesis that bolus weight is reasonably uniform throughout a nonrestrictive range of herbage allowance and that season has a negligible effect on weight of dry matter in the bolus.

\section{Methods}

The study was conducted on the Rangeland Research Area, 3 km west of College Station, Texas. Study sites were dominated by bahiagrass (Paspalum notatum), with minor a mounts of common bermudagrass (Cynodon dactylon) and brownseed paspalum (Paspalum plicatulum). In order to determine the influence of season on boli weights, trials were conducted during midsummer (August 6 to August 17, 1979) and early winter (November 30 to December $6,1979)$. The area for the summer trial was mowed 3 weeks prior to grazing. Excellent soil moisture conditions created forage of high digestibility and moisture content (Table 1). The winter trial site was deferred for 90 days and had received five nights of below freezing temperatures prior to sampling. Forage in the winter trial was of low digestibility and moisture content.

Two esophageally fistulated cows, A and B, weighing 426 and $466 \mathrm{~kg}$, respectively, were allowed to graze at 3- to 5-minute intervals until at least 10 distinct boli could be retrieved through the fistula for each grazing day. Boli were considered "distinct" when all dimensions of the bolus were visible and removal from the collection bag required little displacement of adjacent boli. Boli were collected in an esophageal collection bag with a screen-wire bottom. Both cows were fed known weights of forage each season by hand to determine if complete boli were collected through the fistula by checking for ingesta at the cardia following each swallow. Approximately $95 \%+$ was collected via the esophageal fistula. Animals were fasted 12 hours prior to collection. The boli were then placed in small paper bags, oven dried at $60^{\circ} \mathrm{C}$ for 48 hours, weighed and ground to pass a $1 \mathrm{~mm}$ sieve. This procedure was carried out for five consecutive days on $15 \times 30 \mathrm{~m}$ paddocks $(0.045$ ha) and replicated twice for each season. In order that nutritional characteristics of the diet could be documented, crude protein (CP) (\%) and digestible organic matter (DOM) (\%) analysis was made of boli composited across replication and animal within season for day one and day five. The micro-Kjeldahl procedure was used to determine \% crude protein (AOAC 1965). A modified technique involving the first stage of Tilley and Terry (1963) followed by neutral detergent extraction (Van Soest and Wine 1967) and correction by a forage of known in vivo digestibility was used for determination of DOM.

Standing crop $(\mathrm{kg} / \mathrm{ha})$ was determined on a daily basis by ran- 
Table 1. Seasonal characteristics of available forage and diets of animals at the beginning and end of each replication (day 1 to day 5 ).

\begin{tabular}{|c|c|c|c|c|c|}
\hline \multirow[b]{2}{*}{ Grazing period } & \multirow[b]{2}{*}{ Forage parameter } & \multicolumn{2}{|c|}{ Summer } & \multicolumn{2}{|c|}{ Winter } \\
\hline & & Rep 1 & $\operatorname{Rep} 2$ & Rep 1 & $\operatorname{Rep} 2$ \\
\hline Initial & $\begin{array}{l}\text { Standing crop }\left(\mathrm{g} / \mathrm{m}^{2}\right) \\
\text { Herbage moisture }(\%) \\
\text { Live forage }(\%) \\
\text { Crude protein }(\%) \\
\text { Digestible organic matter }(\%)\end{array}$ & $\begin{array}{l}74^{\mathrm{al}} \\
71 \mathrm{a} \\
96 \mathrm{a} \\
13.0 \\
60\end{array}$ & $\begin{array}{l}110.6^{b} \\
66 a \\
94 a \\
12.8 \\
64\end{array}$ & $\begin{array}{c}73^{\mathrm{a}} \\
32 \mathrm{~b} \\
27 \mathrm{~b} \\
7.9 \\
48\end{array}$ & $\begin{array}{l}64.0^{\mathrm{a}} \\
28 \mathrm{~b} \\
21 \mathrm{~b} \\
8.0 \\
46\end{array}$ \\
\hline Final & $\begin{array}{l}\text { Standing crop }\left(\mathrm{g} / \mathrm{m}^{2}\right) \\
\text { Herbage moisture }(\%) \\
\text { Live forage }(\%) \\
\text { Crude protein }(\%) \\
\text { Digestible organic matter }(\%)\end{array}$ & $\begin{array}{l}52.4 a \\
64 a \\
90^{a} \\
10.9 \\
50\end{array}$ & $\begin{array}{l}28.4 b \\
58 a \\
87 a \\
10.8 \\
52\end{array}$ & $\begin{array}{l}34.8 \mathrm{~b} \\
26 \mathrm{~b} \\
12 \mathrm{~b} \\
5.9 \\
45\end{array}$ & $\begin{array}{l}25.2 \mathrm{~b} \\
18 \mathrm{~b} \\
7 \mathrm{~b} \\
5.4 \\
44\end{array}$ \\
\hline
\end{tabular}

Those values followed by the same letter in a row are not significantly different ( $P \leq 0.05$ ).

domly clipping $10,0.25-\mathrm{m}^{2}$ plots to ground level. Samples were weighed in the field, dried at $100^{\circ} \mathrm{C}$ for 24 hours and reweighed to determine moisture and dry matter content. Daily herbage allowance was then calculated based on daily standing crop and animal body weight and expressed as $\mathrm{kg}$ dry matter standing crop (DM)/ $100 \mathrm{~kg}$ body weight (BW)/day (Hodgson 1979).

Analysis of variance was utilized to test difference in boli weight as influenced by season, replication, and animal. Regression analysis was used to determine the relationship between bolus weight and daily herbage allowance (Steel and Torrie 1960).

\section{Results and Discussion}

\section{Sward Characteristics}

Initial standing crops were similar between replications and season (Table 1). Initially, replication II of the summer trial had significantly greater amounts of forage; however, this difference was not significant by the end of the trial. Replication I of the summer trial had the least change in standing crop. It was felt that the discrepancy was due to sampling error. Daily herbage allowance varied from 15.4 to $4.7 \mathrm{~kg} \mathrm{DM} / 100 \mathrm{~kg} \mathrm{BW} /$ day during the summer trials and 9.6 to $3.4 \mathrm{~kg} \mathrm{DM} / 100 \mathrm{~kg} \mathrm{BW} /$ day during the winter trials. Findings by Allison and Kothmann (1979) and Combrellas and Hodgson (1979) indicate the lower daily herbage allowances attained in these trials approach intake restriction $(5 \mathrm{~kg}$ $\mathrm{DM} / 100 \mathrm{~kg} \mathrm{BW} /$ day) due to limited forage availability.

Herbage moisture content, as expected, was higher in the summer trial as compared to the winter trial. The observed drop in moisture content during each replication of the summer trials was due to declining soil moisture levels and animal selection. Relative humidity coupled with animal selection for green herbage caused the reduction in herbage moisture content during the winter trials. The selectivity for green herbage during the winter trials was evident by a $56-67 \%$ decrease in available live forage from the initial to final grazing day.

\section{Herbage: Bolus Relationship}

Bolus weight was shown not to be greatly affected by daily herbage allowance within the range of observed data (Table 2). Herbage allowance (independent variable) was squared and cubed to determine if improvement in $r^{2}$ could be made in the relationship. Transformation of the daily herbage allowance values resulted in a slight improvement in $r^{2}$ values, yet none of these equations were significant $(P \leq 0.05)$ for the summer or winter trials. Less variability could be accounted for during the winter trials as compared to the summer trials. However, these differences were small.

When bolus weights were compared between cows, no significant differences $(P \leq 0.05)$ could be determined (Table 3$)$. There appeared to be a slightly heavier bolus weight in the heavier cow. It would seem logical that bolus weight should increase as size of the animal increases, yet, this increase would not have to be large in order to meet dry matter intake requirements of a larger animal. The cow size/bolus weight relationship was not consistent between seasons $(P \leq 0.05)$. However, there appeared to be a trend for increasing bolus weight with decreasing moisture content. Again this increase was small.

Table 3. Mean bolus weight (g) and associated confidence intervals across days and replications as influenced by season and cow size. All values reported are not significantly different $(P \leq 0.05)$.

\begin{tabular}{lccc}
\hline & \multicolumn{2}{c}{ Season } & \\
\cline { 2 - 3 } Cow & Summer & Winter & Cow Mean \\
\hline $\mathrm{A}-426 \mathrm{~kg}$ & $4.0 \pm 0.3$ & $4.8 \pm 0.3$ & $4.3 \pm 0.2$ \\
$\mathrm{~B}-466 \mathrm{~kg}$ & $4.3 \pm 0.2$ & $4.7 \pm 0.3$ & $4.5 \pm 0.2$ \\
Season mean & $4.2 \pm 0.2$ & $4.8 \pm 0.2$ & $4.4 \pm 0.1$ \\
\hline
\end{tabular}

Bolus weights averaged across cows and seasons were found to approximate $4.4 \pm 0.1 \mathrm{~g}$. This value is 2.5 to $4.1 \mathrm{~g}$ lower than those reported by Bailey (1961) and Gill et al. (1966), respectively. It must be pointed out that these studies involved hand feeding trials of large Holstein cows. Their findings indicated that bolus weight increased as length of fed leaf material increased. No consistent relationship could be derived in their studies between moisture content and bolus weight. It appeared that if a cow is allowed to accumulate material without having to bite or shear the material, then length of the forage will greatly influence bolus weight. In

Table 2. Equations showing the relationship of bolus weight (g) to herbage allowance (kg/DM/100 $\mathrm{Kg} \mathrm{BW/day)} \mathrm{in} \mathrm{mature} \mathrm{cows.}$

\begin{tabular}{lllll}
\hline \hline Transformation & Equation & $r^{2}$ & S.D. & Significance \\
\hline $\begin{array}{l}\text { Summer Trial } \\
\text { Linear }\end{array}$ & $y=4.45-0.31 \mathrm{x}$ & & & \\
$\quad$ Quadratic & $\mathrm{y}=7.80-0.77 \mathrm{x}+0.04 \mathrm{x}^{2}$ & 0.01 & 1.18 & n.s. \\
$\quad$ Cubic & $\mathrm{y}=5.67+0.51 \mathrm{x}-0.57 \mathrm{x}^{2}+0.003 \mathrm{x}^{3}$ & 0.15 & 1.09 & n.s. \\
Winter Trial & & 0.16 & 1.09 & n.s. \\
$\quad$ Linear & $\mathrm{y}=4.31+0.07 \mathrm{x}$ & 0.01 & 1.08 & n.s. \\
$\quad$ Quadratic & $\mathrm{y}=5.14-0.21 \mathrm{x}+0.02 \mathrm{x}^{2}$ & 0.02 & 1.08 & n.s. \\
Cubic & $\mathrm{y}=-6.41+5.77 \mathrm{x}-0.94 \mathrm{x}^{2}+0.05 \mathrm{x}^{3}$ & 0.09 & 1.04 & n.s. \\
\hline
\end{tabular}


light of these observations, it appears that prehension is a contributing factor in providing uniformity of bolus weights during grazing.

\section{Conclusion}

Data reported appear to support the original hypothesis stating that bolus weight is reasonably uniform throughout a nonrestrictive range of daily herbage allowance and that season has negligible effect on dry matter weight of the bolus. Surprisingly, bolus weight was not influenced by cow size in this study. However, the cows used in this study represent only moderate to large frame animals. Further investigation is required to test this relationship.

These findings lend credence to the idea that measurement of number of swallowed forage boli can provide information on dry matter intake and grazing behavior of an animal. It would require approximately 2000 to 3000 forage boli reported in this study to meet the seasonal daily dry matter requirements of a $450 \mathrm{~kg}$ cow.

\section{Literature Cited}

Allden, W.G., and I.A. Whittaker. 1970. The determinants of herbage intake by grazing sheep: The interrelationship of factors influencing herbage intake and availability. Aust. J. Agr. Res. 21:755-766.

Allison, C.D., and M.M. Kothmann. 1979. Effect of level of stocking pressure on forage intake and diet quality of range cattle. Proc. West. Sec. Amer. Soc. Animal Sci. 30:174-178.

A.0.A.C. 1965. Official methods of analysis (10th Ed.). Washington, D.C. $957 \mathrm{p}$.

Bailey, C.B. 1961. Saliva secretion and its relation to feeding in cattle. Brit. J. Nutr. 15:433-451.
Chacon, E., T.H. Stobbs, and R.L. Sandland. 1976. Estimation of herbage consumption by grazing cattle using measurements of eating behavior. J. Brit. Grassl. Soc. 31:81-87.

Chacon, E., and T.H. Stobbs. 1976. Influence of progressive defoliation of grass sward on the eating behavior of cattle. Aust. J. Agr. Res. 27:709272.

Combellas, J., and J. Hodgson. 1979. Herbage intake and milk production by grazing dairy cows. 1 . The effects of variations in herbage mass and daily herbage allowance in a short-term trail. Grass and Forage Sci. 34:209-214.

Gill, J., R.C. Campling, and D.R. Westgarth. 1966. A study of chewing during eating in the cow. Brit. J. Nutr. 20:13-23.

Hodgson, J. 1979. Nomenclature and definitions in grazing studies. Grass and Forage Sci. 34:11-18.

Schalk, A.F., and R.S. Amadon. 1928. Physiology of the ruminant stomach (Bovine): Study of the dynamic factors. N. Dakota Agr. Exp. Sta. Bull. 216. 64 p.

Spedding, C.R.W., R.V. Large, and D.D. Kydd. 1966. The evaluation of herbage species by grazing animals. Proc. 10th Int. Grassl. Cong., Helsinki, p. 474-483.

Steel, R.G.D., and J.H. Torrie. 1960. Principles and procedures of statistics. McGraw-Hill Book Co., Inc., New York. 481 p.

Stoner, D.C., J.W. Stuth, J.F. Hunter, and H.A. Pearson. 1979. Transduction of changes in esophageal geometry associated with swallowing. Biomed. Sci. Instr. 15:113-116.

Stoner, D.C., J.W. Stuth, A.P. Lucido, J.F. Hunter, and H.A. Pearson. 1980. An implantable telemetry system for monitoring grazing dynamics of wild and domestic ungulates. Biomed. Sci. Instr. 16:123-128.

Stuth, J.W., K.J. Kanouse, J.F. Hunter, H.A. Pearson. 1981. Multiple electrode impedance plethysomography system for monitoring grazing dynamics. Biomed. Sci. Instr. 17:121-124.

Tilley, J.M.A., and R.A. Terry. 1963. A two-stage technique for the in vitro digestion of forage crops. J. Brit. Grassld. Soc. 18:104-111.

Van Soest, P.J., and R.H. Wine. 1967. Use of detergents in the analysis of fibrous feeds. IV. Determinations of plant cell-wall constituents. J. Ass. Off. Agr. Chem. 50:50-55. 